$12-1-2012$

\title{
Spatial and Temporal Trends of Freshwater Mussel Assemblages in the Meramec River Basin, Missouri, USA
}

\author{
J. E. Hinck \\ Stephen E. McMurray \\ Andrew D. Roberts \\ MSU Graduate Student \\ M. Christopher Barnhart \\ Missouri State University \\ Christopher G. Ingersoll
}

See next page for additional authors

Follow this and additional works at: https://bearworks.missouristate.edu/articles-cnas

Part of the Biology Commons

\section{Recommended Citation}

Hinck, Jo Ellen, Stephen E. McMurray, Andrew D. Roberts, M. Christopher Barnhart, Christopher G. Ingersoll, Ning Wang, and Tom Augspurger. "Spatial and temporal trends of freshwater mussel assemblages in the Meramec River basin, Missouri, USA." Journal of Fish and Wildlife Management 3, no. 2 (2012): 319-331.

This article or document was made available through BearWorks, the institutional repository of Missouri State University. The work contained in it may be protected by copyright and require permission of the copyright holder for reuse or redistribution.

For more information, please contact BearWorks@library.missouristate.edu. 


\section{Authors}

J. E. Hinck, Stephen E. McMurray, Andrew D. Roberts, M. Christopher Barnhart, Christopher G. Ingersoll, Ning Wang, and Tom Augspurger 


\title{
Surveys
}

\section{Spatial and Temporal Trends of Freshwater Mussel Assemblages in the Meramec River Basin, Missouri, USA}

\author{
Jo Ellen Hinck,* Stephen E. McMurray, Andrew D. Roberts, M. Christopher Barnhart, \\ Christopher G. Ingersoll, Ning Wang, Tom Augspurger
}

\section{J.E. Hinck, C.G. Ingersoll, N. Wang}

U.S. Geological Survey, Columbia Environmental Research Center, 4200 New Haven Road, Columbia, Missouri 65201

\section{S.E. McMurray}

Missouri Department of Conservation, Central Regional Office and Conservation Research Center, 3500 East Gans Road, Columbia, Missouri 65201

\author{
A.D. Roberts \\ U.S. Fish and Wildlife Service, 101 Park DeVille Drive, Columbia, Missouri 65203 \\ M.C. Barnhart \\ Missouri State University, Department of Biology, 901 South National Avenue, Springfield, Missouri 65897
}

\section{T. Augspurger}

U.S. Fish and Wildlife Service, 551-F Pylon Drive, Raleigh, North Carolina 27636

\begin{abstract}
The Meramec River basin in east-central Missouri has one of the most diverse unionoid mussel faunas in the central United States with $>40$ species identified. Data were analyzed from historical surveys to test whether diversity and abundance of mussels in the Meramec River basin (Big, Bourbeuse, and Meramec rivers, representing $>400$ river miles) decreased between 1978 and 1997. We found that over $20 \mathrm{y}$, species richness and diversity decreased significantly in the Bourbeuse and Meramec rivers but not in the Big River. Most species were found at fewer sites and in lower numbers in 1997 than in 1978. Federally endangered species and Missouri Species of Conservation Concern with the most severe temporal declines were Alasmidonta viridis, Arcidens confragosus, Elliptio crassidens, Epioblasma triquetra, Fusconaia ebena, Lampsilis abrupta, Lampsilis brittsi, and Simpsonaias ambigua. Averaged across all species, mussels were generally being extirpated from historical sampling sites more rapidly than colonization was occurring. An exception was one reach of the Meramec River between river miles 28.4 and 59.5, where mussel abundance and diversity were greater than in other reaches and where colonization of Margaritiferidae, Lampsilini, and Quadrulini exceeded extirpation. The exact reasons mussel diversity and abundance have remained robust in this 30-mile reach is uncertain, but the reach is associated with increased gradients, few long pools, and vertical rock faces, all of which are preferable for mussels. Complete loss of mussel communities at eight sites (16\%) with relatively diverse historical assemblages was attributed to physical habitat changes including bank erosion, unstable substrate, and sedimentation. Mussel conservation efforts, including restoring and protecting riparian habitats, limiting the effects of in-stream sand and gravel mining, monitoring and controlling invasive species, and protecting water quality, may be warranted in the Meramec River basin.
\end{abstract}

Keywords: extirpation; field survey; freshwater mussels; status; Unionoidea

Received: May 8, 2012; Accepted: August 14, 2012; Published Online Early: August 2012; Published: December 2012 Citation: Hinck JE, McMurray SE, Roberts AD, Barnhart MC, Ingersoll CG, Wang N, Augspurger T. 2012. Spatial and temporal trends of freshwater mussel assemblages in the Meramec River basin, Missouri, USA. Journal of Fish and Wildlife Management 3(2):319-331; e1944-687X. doi: 10.3996/052012-JFWM-038

Copyright: All material appearing in the Journal of Fish and Wildlife Management is in the public domain and may be reproduced or copied without permission unless specifically noted with the copyright symbol $\odot$. Citation of the source, as given above, is requested.

The findings and conclusions in this article are those of the author(s) and do not necessarily represent the views of the U.S. Fish and Wildlife Service.

* Corresponding author: jhinck@usgs.gov 


\section{Introduction}

Native unionoid mussels (Mollusca: Bivalvia: Unionoidea; Carter et al. 2011) are important components of aquatic ecosystems. Global declines have resulted in native mussels being identified as the most imperiled faunal group in North America, which emphasizes the need for their protection and conservation. At least 26 and probably $>40$ of the $\sim 300$ North American taxa have become extinct in the past $100 \mathrm{y}$, and it appears that $>25 \%$ of the mussel fauna will be lost within the next 30 y (Haag 2009). Presently, 73 mussel species are classified as federally threatened or endangered pursuant to the U.S. Endangered Species Act (ESA 1973, as amended), with 7 additional species as candidates for listing in the United States (U.S. Fish and Wildlife Service 2011). Declines in mussels have been attributed to various factors, including sedimentation, channelization, dredging, impoundment construction and operation, pollution, and invasive species (Lydeard et al. 2004).

At least 69 species of native mussels have historically occurred in Missouri (Missouri Department of Conservation 2008). The Meramec River basin in east-central Missouri contains one of the most diverse mussel faunas in the central United States, with $>40$ species (Buchanan 1980; Roberts and Bruenderman 2000), several of which are listed as federal or state endangered species. The status of mussels in the basin was initially surveyed in 1977-1978 following proposals to construct multiple flood-control dams in the Meramec River basin (Buchanan 1980). A second survey was conducted in 1997 to address concerns about declines in mussel diversity and abundance (Roberts and Bruenderman 2000). The mussel community in the Big River, the largest tributary of the Meramec River, was of specific concern because of leadzinc and barite (barium sulfate) mining that occurred in the upper and middle reaches of the Big River watershed. Historical mining has been implicated in heavy metal contamination of aquatic biota, including mussels, in the Big River (Niethammer et al. 1985; Czarnezki 1985, 1987; Schmitt et al. 1987; Gale et al. 2002; Besser et al. 2007, 2009a, 2009b).

In addition to mining, other threats to mussel conservation exist in the Meramec River basin. Although water quality is considered good compared with other basins in the state, point and nonpoint source pollution from hundreds of dischargers occurs within the basin (Annis et al. 2009). Construction activities to accommodate human population growth, especially in the lower portion of the basin, can also impact water quality through hydrologic alteration and by increasing inputs of sediments and contaminated runoff. Livestock grazing, logging, and in-stream gravel mining are major activities within the basin that have the potential to impact mussel populations through runoff, erosion, sediment production, and nutrient loading.

The objective of this study was to analyze data from historical surveys to document and evaluate trends in spatial and temporal diversity and abundance of mussels in the Meramec River basin (Buchanan 1980; Roberts and
Bruenderman 2000). Specifically, we hypothesized that mussel diversity and abundance decreased between 1978 and 1997 in the three largest rivers in the Meramec River basin. Trends in diversity and abundance of mussels, particularly Missouri Species of Conservation Concern (SOCC, which includes federal and state threatened or endangered species) were summarized by river and individual sites.

\section{Methods}

\section{Study area}

The study area $\left(10,255 \mathrm{~km}^{2}\right)$ included the Meramec River and two major tributaries, the Bourbeuse River and the Big River, in the Ozark Plateau Province in eastcentral Missouri (Figure 1). The Meramec River flows northeast for $351 \mathrm{~km}$ from the Salem Plateau of the Ozark Highlands to the Mississippi River downstream of St. Louis, Missouri. The watershed of the upper Meramec (upstream of River Mile [RM] 95) is primarily forest and pasture with little urbanization, whereas the lower basin is heavily populated. The lower Meramec River is wider and flows more slowly than the upper river, and its extreme lower reaches are influenced by backflows of the Mississippi River. The Bourbeuse River lies to the north of the Meramec River and flows northeast $240 \mathrm{~km}$ through a largely rural area until reaching the Meramec River at RM 68. The Bourbeuse is considered a lowland river with normally high turbidity, and the watershed is primarily forest $(55 \%)$ and pasture $(32 \%$; Homer et al. 2004). The Big River lies southeast of the Meramec River and flows north $225 \mathrm{~km}$ until reaching the Meramec River at RM 38. Land use in the Big River drainage is primarily forest $(72 \%)$ and pasture (16\%), but the lower basin is becoming rapidly urbanized. Degradation of habitat and biota, including mussels, due to historical mining in the Big River watershed has been well-documented (e.g., Besser et al. 2009b; Roberts et al. 2009; Allert et al. 2010).

\section{Sampling methods}

Buchanan (1980) surveyed mussels at 198 sites in 1977-1978 (henceforth referred to as 1978) to determine the distribution, relative abundance, and habitat requirements for mussel species, with an emphasis on four SOCC (Cumberlandia monodonta, Cyprogenia aberti, Lampsilis abrupta, Leptodea leptodon) known or suspected to occur in the Meramec River basin. Streams were sampled every $8 \mathrm{~km}$ ( 5 miles) unless access was restricted or mussels were absent at two consecutive sites.

Roberts and Bruenderman (2000) surveyed mussels at 50 sites in the Meramec River $(n=28)$, Bourbeuse River ( $n=17)$, and Big River $(n=5)$ in 1997. Sites where currently listed SOCC were found in the 1978 survey were resampled along with new sites to update knowledge of the status of the mussel fauna in the Meramec River basin (Roberts and Bruenderman 2000; Figure 1). The two surveys used similar methodology to allow for comparisons. Briefly, sampling during both surveys was carried out by timed, qualitative searches, with the primary objective to locate rare and endangered 


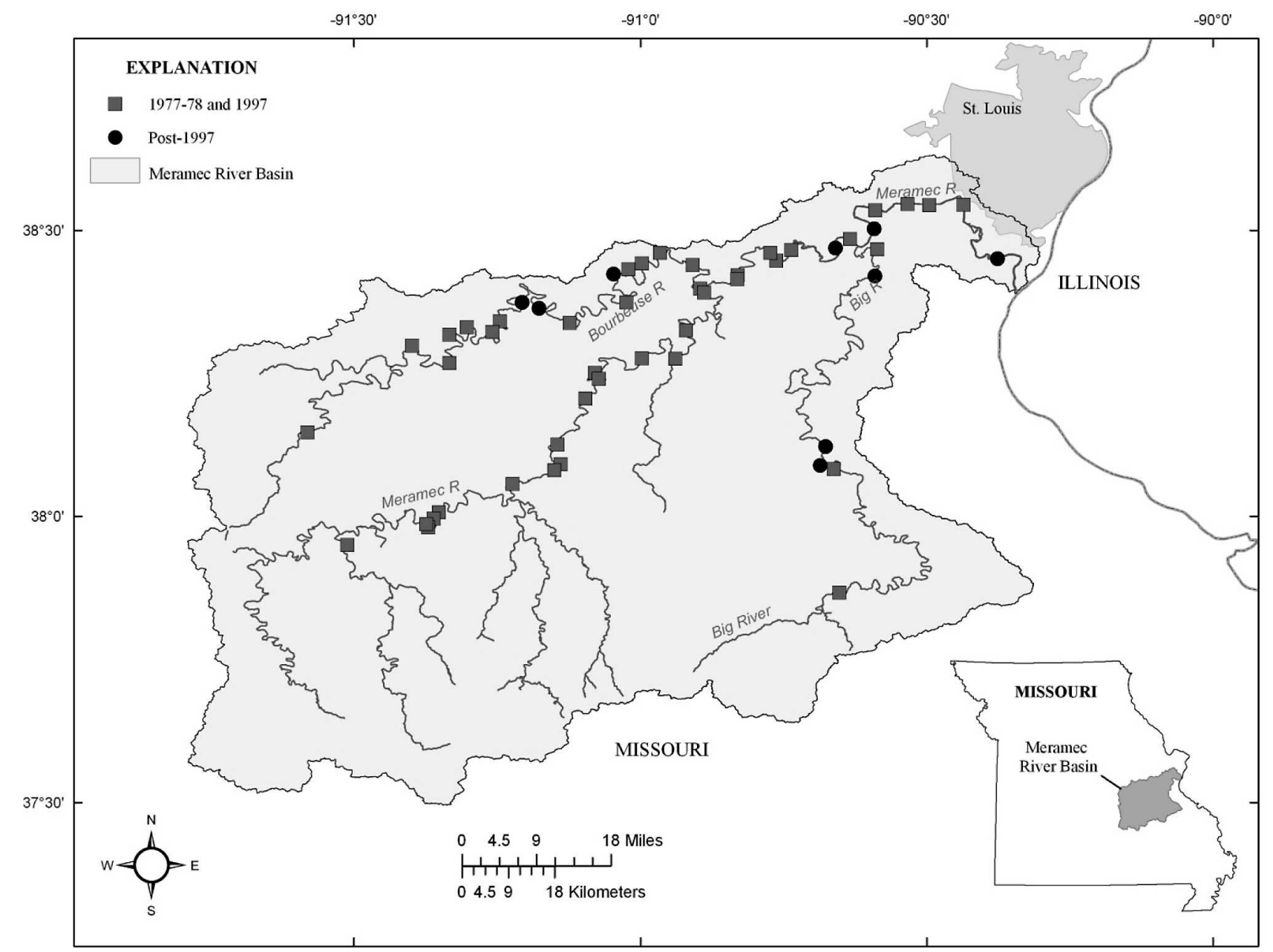

Figure 1. Meramec River basin (Missouri) map showing sites sampled for freshwater mussels in 1978 and 1997 (gray boxes) and those resampled after 1997 (black circles).

mussel species over a broad spatial scale, a design not uncommon to state and federal management agencies. Mussels were collected by hand while snorkeling, wading, and diving. We attempted to match sampling effort (person-hours) of the 1978 survey for each site (expressed as catch per unit effort [CPUE]; see below). Sampling effort (i.e., time spent sampling individual sites) differed between surveys, which can lead to bias in species richness estimates (e.g., Huang et al. 2011), but the lower sampling effort for a site was not consistent between surveys. In 1997, the entire sampling area of the 1978 survey was searched. If no mussels or suitable habitat were encountered in 1997, sampling crews moved on to other sites rather than continuing to search unoccupied habitat for the mere purpose of matching 1978 sampling efforts (Roberts and Bruenderman 2000). Mussels were identified; classified as living, dead, weathered, or subfossil; and returned to the substrate. The number of living individuals of each species was recorded. Sites were identified by river mile (e.g., RM 6.9) as opposed to metric units to facilitate comparison with sample locations evaluated in previous publications (Buchanan 1980; Roberts and Bruenderman 2000). Results of these surveys have bias because qualitative searches are more likely to locate mussel species that are large, surface-dwelling, and have distinctive shell sculpture than species that are small, deeply buried, and smooth-shelled (Vaughn et al. 1997; Strayer and Smith 2003). The seasonal vertical migration of freshwater mussels (e.g., Perles et al. 2003) may affect the detectability of individual species. However, all surveys were conducted during seasons considered optimal for observing freshwater mussel populations in Missouri (from spring through autumn), when water temperature and photoperiod differ minimally in the Meramec River basin, and during periods of low flow, thereby minimizing the effects water clarity and depth would have on detectability between the surveys.

Several sites were resampled opportunistically at irregular intervals after 1997 (Figure 1) to search for mussel broodstock for artificial propagation research (e.g., Barnhart 2009). Sites resampled after 1997 comprising the Meramec RM 6.9, 33.5, and 39.8; Bourbeuse RM 24.6, 53.9, and 66.3; and Big RM 10.3, 62.7, and 65.7 were included in this paper to evaluate temporal trends of mussel distribution and abundance. These additional collections used the same methodologies described for the 1978 and 1997 surveys, except sampling times were 
not always similar. During post-1997 collections, the entire area identified as the mussel bed in 1978 and 1997 was searched, and all species and individuals encountered were recorded. Additional areas that may harbor mussels but were possibly not sampled during 1978 were also searched to maximize the likelihood of encountering rare species.

\section{Data analyses}

We used mussel survey data to estimate community characteristics at individual sites (Data S1, Supplemental Material). We revised taxonomy where necessary to follow current usage. Metrics that we analyzed included species richness, CPUE (mussels/person-hour), and Shannon diversity index (Shannon 1948). We calculated colonization proportion (Pc) and extirpation proportion (Pe) for each species and analyzed them by taxa (Vaughn 2012). For each species, colonization was the number of sites colonized between 1978 and 1997 divided by the total number of sites unoccupied in 1978. Extirpation was the number of sites that were occupied in 1978 only divided by the total number of occupied sites (1978 occurrences plus 1997 occurrences). Examination of richness and CPUE data revealed that mussels in Meramec River between RM 28.4 and 59.5 were generally more abundant and diverse than in other reaches in the Meramec River in 1997. Therefore, we evaluated Pc and $\mathrm{Pe}$ in these reaches separately (Table S1, Supplemental Material). Community composition metrics included relative abundance of SOCC and common species (Actinonaias ligamentina, Amblema plicata), which were generally ubiquitous and abundant throughout the Meramec River basin. We also computed the relative abundances of certain taxa. Nonnative Asian clams (Corbicula fluminea) were found at most sites but were not included in the data analysis.

We compared the CPUE between two groups of species: those in the tribe Lampsilini and those in the tribes Amblemini + Pleurobemini + Quadrulini (APQ taxa). We compared these two groups because of their differing life histories and perceived differences in their responses to stress. Lampsilini generally have relatively thin shells and are mobile. Most lampsilines mature rapidly (within 2-3 y), are long-term brooders, and are generally short-lived ( $<10$ y; Haag and Rypel 2011). The APQ taxa are relatively heavy-shelled and less mobile as adults. The APQ taxa are also slower to reach sexual maturity $(>3 \mathrm{y})$, are short-term brooders, and longer lived (several decades; Haag and Rypel 2011). Healthy mussel communities in the Mississippi River basin generally have approximately equal numbers of Lampsilini and APQ taxa, and skewed ratios of these taxa may indicate a problem (H. Dunn, Ecological Specialists, Inc., personal communication). The APQ taxa appear to be more tolerant than Lampsilini of temperature changes, siltation, or water quality degradation (e.g., Tetzloff 2001).

We performed statistical analyses with Version 9.2 of the Statistical Analysis System (SAS Institute, Cary, NC). Only sites sampled in 1978 and 1997 were included in the data analysis. We calculated arithmetic means and standard errors for community metrics by river and survey year, and we evaluated differences using the nonparametric Kruskal-Wallis test. Community characteristics for sites resampled after 1997 were calculated but not tested statistically because of the variation in sampling effort and limited number of sites; however, trends are described. Additional distribution, abundance, and diversity data for individual species and at individual sites are presented as supplemental information (Figure S1; Tables S1-S3, Supplemental Material).

\section{Results}

\section{Community metric differences among rivers and between qualitative surveys}

Species richness was lower in 1997 than in 1978 in the Meramec, Bourbeuse, and Big rivers (Table 1; Figure S1, Supplemental Material). The differences were significant in the Meramec River $(H=7.84, P<0.01)$ and Bourbeuse River $(H=18.16, P<0.01)$ but not in the Big River $(H=$ 1.10, $P=0.29$ ), which had the smallest number of sites $(n=5)$. Species richness was significantly greater in the Bourbeuse River than in the Meramec River $(H=4.36$, $P=0.04)$ and Big River $(H=7.14, P<0.01)$ in 1978 , but species richness did not differ among the three rivers in 1997 (Table 1). Within the Big River, most species were found at RM 4.8 and 10.3 in 1997, with other sites contributing little to richness (Figure S1, Supplemental Material).

The CPUE was lower in 1997 compared with 1978 in all rivers but was only significantly lower in the Bourbeuse River $(H=14.22, P<0.01$; Table 1; Figure S1, Supplemental Material). Among the three rivers, the CPUE was significantly lower in Meramec River than in the Bourbeuse River in $1978(H=9.99, P<0.01)$. The CPUE did not differ among the three rivers in 1997, but was generally lowest in the Bourbeuse River and Big River (Table 1). Local extirpation of living mussel communities were noted at eight sites resampled in 1997, including RM 102.4, 106.5, 125.2, 145.1, and 145.7 in the Meramec River; RM 0.4 in the Bourbeuse River; and RM 62.7 and 120.4 in the Big River.

Mussel diversity (as Shannon diversity index) was significantly lower in 1997 compared with 1978 in the Meramec River $(H=7.28, P<0.01)$ and the Bourbeuse River $(H=11.40, P<0.01)$; the difference was not significant in the Big River, where diversity was low in 1978 (Table 1; Figure S1, Supplemental Material). Mussel diversity was significantly lower in the Big River than in the Bourbeuse River in $1978(H=5.71, P=0.02)$, but differences in diversity among the three rivers were not significant in 1997 (Table 1).

The percentage of the mussel community represented as SOCC did not differ significantly between surveys in the Meramec, Bourbeuse, or Big rivers (Table 1). However, SOCC comprised a significantly greater proportion of the mussel community in the Meramec River than the Bourbeuse River in $1978(H=11.23, P<0.01)$ and $1997(H=5.68, P=0.02$; Table 1$)$. Sites with SOCC comprising the majority of the mussel community in 1997 were in the upper Meramec River (RM 115.6 to 
Table 1. Mean ( $\pm \mathrm{SE}$, range in parenthesis) species richness, catch per unit effort (CPUE), and Shannon Diversity Index (SDI) for mussel surveys in the Meramec River basin, Missouri, by year. Community metrics including the relative abundance of Missouri Species of Conservation Concern (SOCC), species in the tribes Amblemini, Pleurobemini, and Quadrulini (APQ taxa), Lampsilini, and common species (A. plicata, A. ligamentina) are also presented. Values for a parameter within each row followed by the same letter were not significantly different among sites $(P>0.05$, Kruskal-Wallis test). For each river, 1997 values followed by an asterisk were significantly different from 1978 values for individual parameters $(P<0.05$, Kruskal-Wallis test).

\begin{tabular}{|c|c|c|c|c|c|c|}
\hline Parameter, year & \multicolumn{2}{|c|}{ Meramec River $(n=28)$} & \multicolumn{2}{|c|}{ Bourbeuse River $(n=17)$} & \multicolumn{2}{|l|}{ Big River $(n=5)$} \\
\hline \multicolumn{7}{|l|}{ Species richness } \\
\hline 1978 & $14.1 \pm 1.4(0-28)$ & A & $18.4 \pm 1.2(4-24)$ & B & $9.4 \pm 2.7(1-16)$ & $A$ \\
\hline 1997 & $8.1 \pm 1.7(0-26)$ & $A^{*}$ & $6.9 \pm 1.3(0-18)$ & $A^{*}$ & $6.0 \pm 3.0(0-15)$ & A \\
\hline \multicolumn{7}{|c|}{ CPUE (mussels/person-hour) } \\
\hline 1978 & $27.1 \pm 5.5(0-112)$ & A & $64.1 \pm 13.5(11-238)$ & B & $27.3 \pm 12.5(2-70)$ & $A B$ \\
\hline 1997 & $24.5 \pm 8.1(0-190)$ & A & $15.6 \pm 4.7(0-67)$ & $A^{*}$ & $14.8 \pm 9.8(0-53)$ & A \\
\hline \multicolumn{7}{|l|}{ SDI } \\
\hline 1978 & $1.74 \pm 0.11(0-2.9)$ & $A B$ & $1.99 \pm 0.08(1.2-2.5)$ & $B$ & $1.09 \pm 0.37(0-2.1)$ & $A$ \\
\hline 1997 & $0.94 \pm 0.18(0-2.5)$ & $A^{*}$ & $1.20 \pm 0.18(0-2.2)$ & $A^{*}$ & $0.97 \pm 0.42(0-2.0)$ & $A$ \\
\hline \multicolumn{7}{|c|}{ SOCC abundance (\%) } \\
\hline 1978 & $18.5 \pm 3.8(0-59)$ & B & $2.8 \pm 0.9(0-14)$ & A & $17.9 \pm 11.3(0-57)$ & $A B$ \\
\hline 1997 & $30.1 \pm 8.5(0-100)$ & B & $4.2 \pm 1.9(0-29)$ & A & $15.3 \pm 14.9(0-45)$ & $A B$ \\
\hline \multicolumn{7}{|l|}{ APQ abundance (\%) } \\
\hline 1978 & $45.6 \pm 4.1(10-100)$ & $B$ & $22.9 \pm 4.4(0-36)$ & A & $38.0 \pm 19.8(0-94)$ & $A B$ \\
\hline 1997 & $32.0 \pm 6.4(0-91)$ & A & $18.7 \pm 5.0(0-54)$ & A & $51.4 \pm 15.9(20-71)$ & ) $A$ \\
\hline \multicolumn{7}{|c|}{ Lampsilini abundance (\%) } \\
\hline 1978 & $40.4 \pm 3.8(0-87)$ & A & $66.9 \pm 4.2(35-100)$ & ) $B$ & $39.9 \pm 16.3(5-100)$ & ) $A B$ \\
\hline 1997 & $45.3 \pm 7.4(0-100)$ & A & $71.9 \pm 6.9(0-100)$ & B & $47.7 \pm 16.3(27-80)$ & ) $A B$ \\
\hline \multicolumn{7}{|c|}{ Common species abundance (\%) } \\
\hline 1978 & $36.9 \pm 4.3(0-71)$ & B & $20.6 \pm 5.2(0-59)$ & A & $33.7 \pm 20.7(0-91)$ & $A B$ \\
\hline 1997 & $26.8 \pm 5.9(0-71)$ & $A$ & $13.0 \pm 3.8(0-50)$ & A & $36.4 \pm 19.3(0-66)$ & A \\
\hline
\end{tabular}

165.9) where overall species richness was low (Figure S1, Supplemental Material). The SOCC exhibiting the most severe temporal declines in distributions at historical survey sites are $A$. viridis, $A$. confragosus, $E$. crassidens, $E$. triquetra, F. ebena, L. brittsi, L. abrupta, and S. ambigua (Table S2, Supplemental Material).

Relative abundance of APQ taxa and Lampsilini was not significantly different between 1978 and 1997 in the Meramec, Bourbeuse, or Big rivers (Table 1). The APQ taxa comprised a significantly greater proportion of the mussel community in the Meramec River than the Bourbeuse River in $1978(H=10.51, P<0.01)$, but APQ abundance was not significantly different among the three rivers in 1997 (Table 1; Figure S1, Supplemental Material). Lampsilini relative abundance was significantly greater in the Bourbeuse River than the Meramec River in $1978(H=15.53, P<0.01)$ and $1997(H=5.57, P=0.02$; Table 1).

The relative abundance of common species ( $A$. plicata and $A$. ligamentina) was lower in 1997 than in 1978 in the Meramec and Bourbeuse rivers but greater in the Big River, but these differences were not statistically significant (Table 1; Figure S1, Supplemental Material). In 1978, common species abundance was significantly greater in the Meramec River than in the Bourbeuse River $(H=5.41, P=0.02$; Table 1$)$; however, differences among the three rivers were not significant in 1997.

\section{Extirpation and colonization}

Averaged across species, Pe exceeded Pc at sites in the Meramec River, Bourbeuse River, and Big River (Figure 2). The only exception was for Margaritiferidae (C. monodonta) in the Meramec River. The Pe among rivers were not significantly different $(H=4.55, P=0.10)$, but $P C$ was significantly lower in the Bourbeuse River than in the Meramec River $(H=7.80, P<0.01)$. The $P e$ by taxa ranged from 0.20 to 0.72 in the Meramec River, 0.55 to 1.00 in the Bourbeuse River, and 0 to 0.68 in the Big River. The Pc by taxa ranged from 0 to 0.28 in the Meramec River, 0 to 0.09 in the Bourbeuse River, and 0 to 0.31 in the Big River (Figure 2). Differences in Pe and Pc were significant in the Meramec River for Anodontini $(H=8.60, P<0.01)$, Lampsilini $(H=19.96, P<0.01)$, Pleurobemini $(H=8.64, P<0.01)$, and Quadrulini $(H=$ 4.66, $P=0.03$; Figure 2). In the Bourbeuse River, Pe was significantly greater than Pc for Anodontini $(H=11.98$, $P<0.01)$, Lampsilini $(H=25.12, P<0.01)$, and Pleurobemini $(H=6.05, P=0.01)$. Differences in the 
Big River were only significant for Anodontini $(H=7.92$, $P<0.01$; Figure 2).

The Pe and Pc of species within the Meramec River were not consistent with patterns among river reaches (Figure 3). The Pe were consistently lower for all taxa between RM 28.4 and 59.5 (range 0-0.50) compared with upstream (range 0.14-1.00) and downstream (range 0.25-0.75) reaches; differences were significant for Anodontini, Lampsilini, and Quadrulini (Figure 3). The Pc in the Meramec River were $0-0.31$ upstream of RM 59.5 (range 0-0.2 excluding Margaritiferidae), 0.11-0.35 between RM 28.4 and 59.5, and 0-0.17 downstream of RM 28.4, and these differences among reaches were significant for Anodontini, Lampsilini, and Quadrulini (Figure 3). The Pc was greater than Pe for Lampsilini, Margaritiferidae, and Quadrulini between RM 28.4 and 59.5, but these differences were not significant.

\section{Species trends at sites resampled after 1997}

Sites resampled after 1997 generally showed continued mussel declines (Table 2). Changes in species richness were difficult to assess given the variation in sampling times in surveys conducted after 1997. However, few species were found at Bourbeuse RM 24.6 in 2005 despite lengthy sampling efforts at these sites (Table 2). Decreases in Shannon diversity index and CPUE were greatest for the most recent collections at Meramec RM 6.9 and 39.8 and Bourbeuse RM 24.6. Conversely, species richness, CPUE, Shannon diversity index, and community abundance measures have been relatively stable or increasing at Bourbeuse RM 53.9 and at Big RM 10.3.

The APQ taxa were dominant at Meramec RM 6.9 and at Big RM 10.3, while lampsilines were the most abundant tribe at other sites (Table 2; Figure 4). Relative abundances of lampsilines and APQ taxa were stable at Big RM 10.3, while sites upstream were more variable (Table 2). The CPUE for these taxa at individual sites in the Meramec River basin has fluctuated since 1997 but generally shows a decreasing trend (Figure 4). One post1997 sampling event at Meramec RM 33.5 had CPUEs greater than in 1997. Increased CPUE was generally from the presence of more Lampsilini (A. ligamentina). The CPUE has remained low at Bourbeuse RM 24.6 and 53.9 since 1997. The CPUE between 2000 and 2008 has remained lower than 1997 values in the Big River (Figure 4). Compared with sites in the Meramec and Bourbeuse rivers, the CPUE was low $(<8)$ at RM 62.7 and 65.7 in the Big River regardless of sampling year.

\section{Discussion}

Significant decreases in diversity and abundance and increases in extirpation of species were evident at historical survey sites in the Meramec River basin, a pattern that continues to be reported in multiple U.S. river systems (Warren and Haag 2005; Hanlon et al. 2009; Wendeln et al. 2009; Haag and Warren 2010). Although mussel populations in the Meramec River basin appear more stable in terms of diversity and abundance than other regions (e.g., Abell et al. 2000), decreases in SOCC
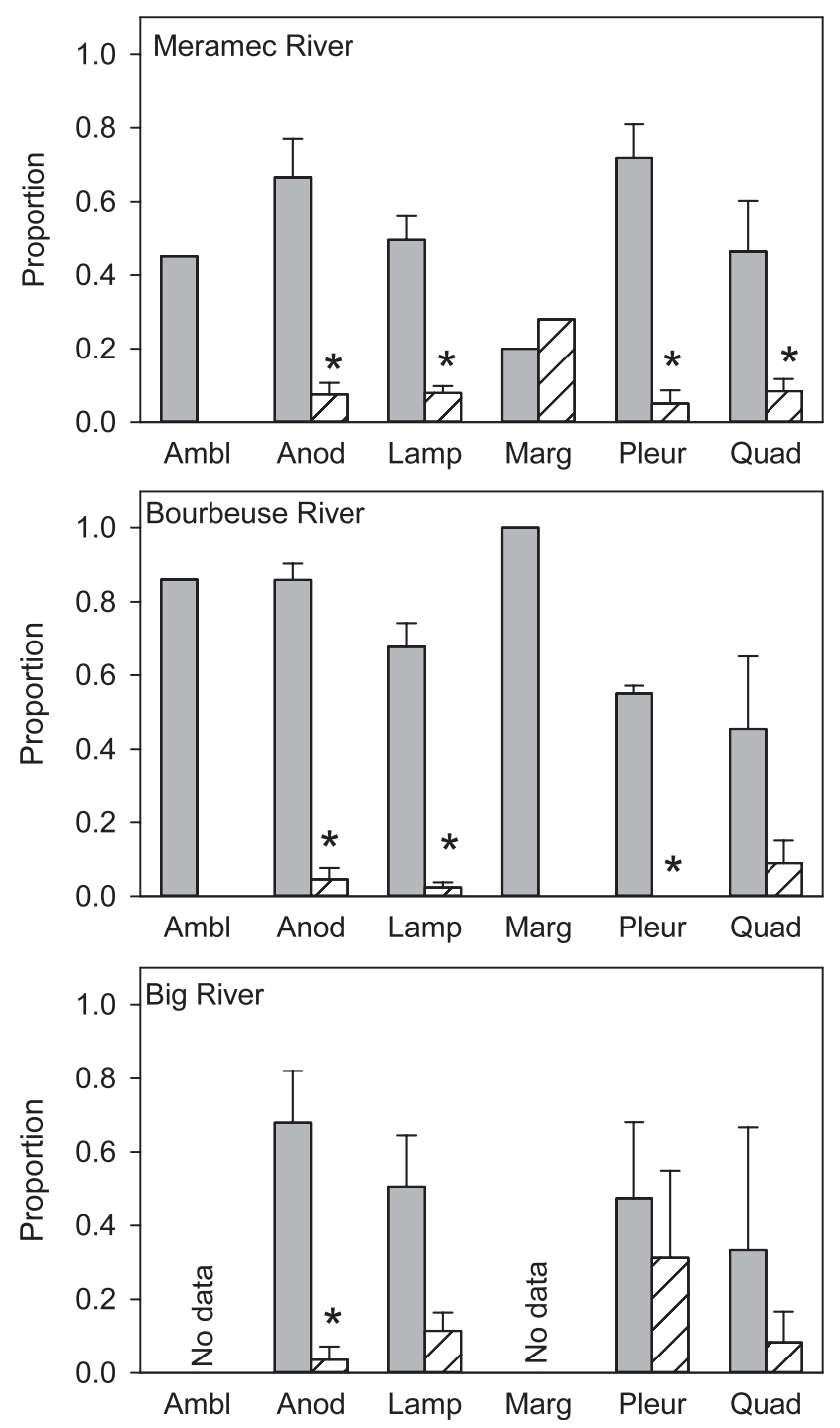

Figure 2. Mean ( \pm SE) extirpation (gray bar) and colonization (white hatched bar) proportions of freshwater mussel species by taxa and river in the Meramec River basin, Missouri, between 1978 and 1997. Asterisks denote significant differences between extirpation and colonization proportions within each taxa $(P<0.05$, Kruskal-Wallis test). Missing bars indicate a proportion of zero unless otherwise noted. Ambl, Amblemini; Anod, Anodontini; Lamp, Lampsilini; Marg, Margaritiferidae; Pleur, Pleurobemini; Quad, Quadrulini.

distribution indicate that increased mussel conservation actions in the basin may be warranted.

Mussel distribution may change over time with natural changes in river morphology. Resurveying 1978 sites in 1997 cannot account for the formation of new mussel habitat (i.e., mussel beds) that may have occurred in the 20-y time period between surveys; the data only reflect changes at the resurveyed sites. New sites surveyed in 1997 (Roberts and Bruenderman 2000) provide additional insight on mussel occurrence and the status of species, but these data cannot be used to determine whether new beds have been formed. The loss of entire mussel beds at eight sites in $20 \mathrm{y}$ is a cause for concern to 

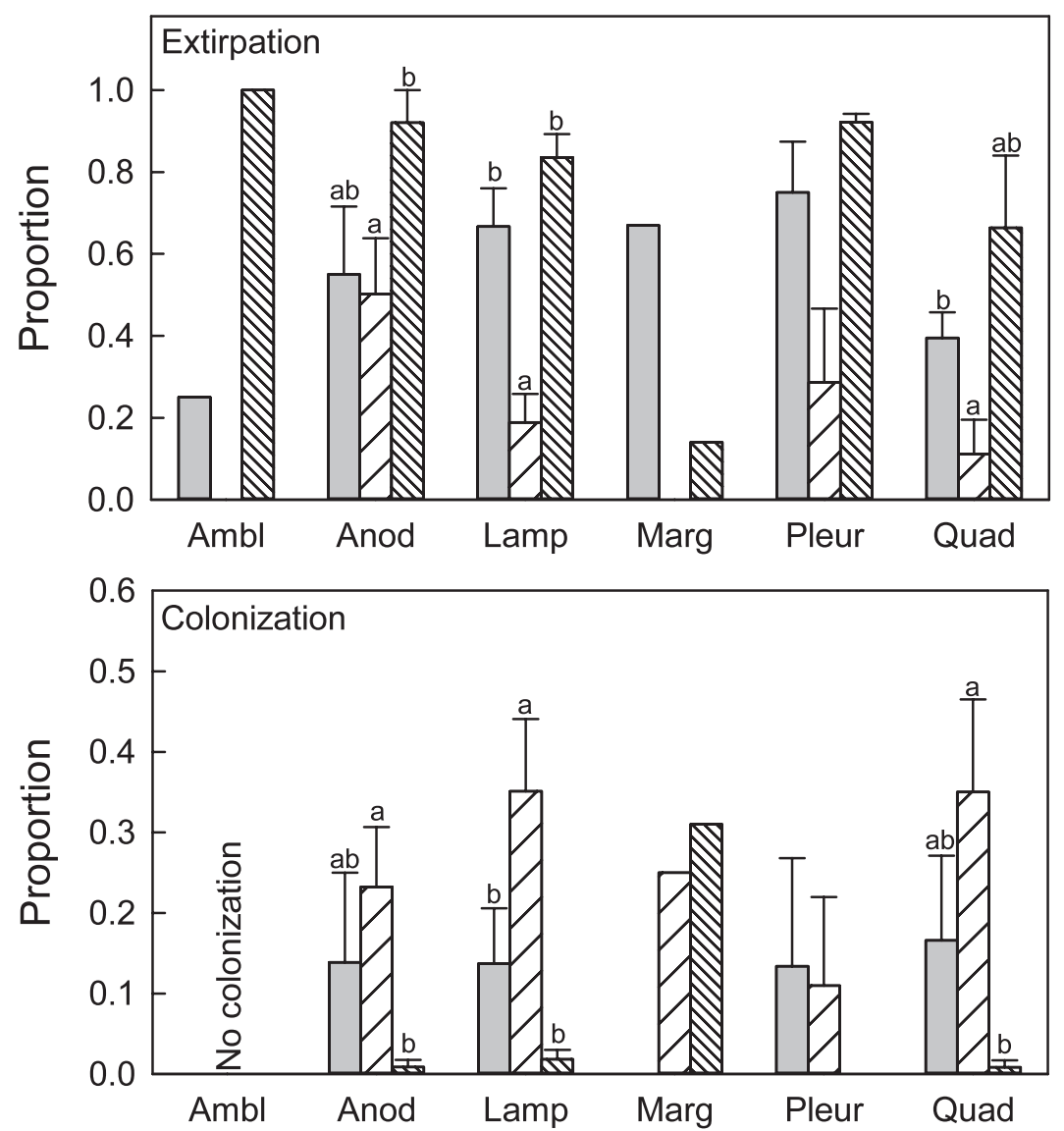

Figure 3. Mean $( \pm \mathrm{SE})$ extirpation and colonization proportions of freshwater mussel species by taxa and reach of Meramec River, Missouri, between 1978 and 1997. Letters on top of bars indicated that colonization or extirpation were significantly different within each taxa $(P<0.05$, Kruskal-Wallis test). Missing bars indicate a proportion of zero unless otherwise noted. Ambl, Amblemini; Anod, Anodontini; Lamp, Lampsilini; Marg, Margaritiferidae; Pleur, Pleurobemini; Quad, Quadrulini.

resource managers because the natural process of mussel bed formation would be slower. These sites that supported diverse mussel beds in 1978 were found to have unsuitable habitat in 1997; fine, loosely packed gravel, lack of any coatings of algae or diatoms on gravel (indicating that gravel is actively moving), and lack of finer substrates were observed in 1997 (Roberts and Bruenderman 2000). Collection of mussels has not been attempted at any of these eight sites since 1997.

Mussels are being extirpated at historical sampling sites more rapidly than colonization is occurring. This trend does not appear to be species related, because differences between $\mathrm{Pe}$ and $\mathrm{Pc}$ were significant for all taxa. High Pe values, in part, were related to low population sizes of species in 1978 (Gotelli 2001). Vaughn (2012) determined that local extirpation of mussels over an 80-y time period in the Red River drainage of Oklahoma and Texas was greatest in rare species and lowest in highly abundant species. Rare species in the Meramec River basin did have high Pe, but extirpation at historical sampling sites was also high in abundant species including $A$. plicata, A. ligamentina, L. cardium, P. alatus, and E. dilatata. Despite differences in species composition and time between surveys, Pe and Pc of mussels in the Meramec River basin were similar to those reported by Vaughn (2012). An exception to these trends occurred in the Meramec River between RM 28.4 and 59.5, where colonization was greater than extirpation for Anodontini, Lampsilini, and Quadrulini.

The three surveyed rivers of the Meramec River basin differed in mussel composition and abundance, but most species were found at fewer sites and in lower numbers in 1997 compared with 1978, regardless of the river. Amblema plicata and A. ligamentina, commonly considered to be habitat generalists, dominated musselassemblage composition at most sites in the Meramec, Bourbeuse, and Big rivers. Mussels were most diverse and abundant in the Meramec River between RM 28.4 and RM 59.5, while relatively few mussels were found in 
Table 2. Summary of sampling time (minutes), species richness, catch per unit effort (CPUE; mussels/person-hour), Shannon Diversity Index (SDI), relative abundance (\%) of Missouri Species of Conservation Concern (SOCC), species in the tribes Amblemini, Pleurobemini, and Quadrulini (APQ taxa), Lampsilini, and common species (A. plicata, A. ligamentina) in mussel surveys at specific river mile (RM) locations in the Meramec River basin, Missouri, from 1978 to 2008.

\begin{tabular}{|c|c|c|c|c|c|c|c|c|}
\hline \multirow[b]{2}{*}{ Site, year } & \multirow[b]{2}{*}{$\begin{array}{c}\text { Sampling } \\
\text { time }\end{array}$} & \multirow[b]{2}{*}{$\begin{array}{l}\text { Species } \\
\text { richness }\end{array}$} & \multirow[b]{2}{*}{ CPUE } & \multirow[b]{2}{*}{ SDI } & \multicolumn{4}{|c|}{ Relative abundance } \\
\hline & & & & & socc & APQ taxa & Lampsilini & $\begin{array}{c}\text { Common } \\
\text { species }\end{array}$ \\
\hline \multicolumn{9}{|c|}{ Meramec River RM 6.9} \\
\hline 1978 & 690 & 19 & 59.9 & 1.69 & 1.0 & 85 & 12 & 46 \\
\hline 1997 & 900 & 13 & 28.1 & 1.33 & 2.1 & 91 & 7 & 64 \\
\hline 2000 & 75 & 4 & 4.8 & 1.33 & 16.7 & 83 & 0 & 33 \\
\hline \multicolumn{9}{|c|}{ Meramec River RM 33.5} \\
\hline 1978 & 1,380 & 24 & 36.1 & 1.99 & 8.1 & 64 & 26 & 46 \\
\hline 1997 & 1,395 & 24 & 14.4 & 2.45 & 16.5 & 24 & 64 & 30 \\
\hline 2002 & 90 & 10 & 15.3 & 2.25 & 13.0 & 48 & 43 & 22 \\
\hline 2003 & 180 & 13 & 40.0 & 1.71 & 5.0 & 20 & 79 & 62 \\
\hline 2007 & 240 & 8 & 7.5 & 1.39 & 6.7 & 30 & 70 & 73 \\
\hline \multicolumn{9}{|c|}{ Meramec River RM 39.8} \\
\hline 1978 & 490 & 23 & 68.7 & 1.90 & 5.4 & 44 & 56 & 65 \\
\hline 1997 & 990 & 22 & 36.2 & 1.89 & 2.7 & 29 & 71 & 66 \\
\hline 2007 & 240 & 2 & 1.5 & 0.64 & 0 & 0 & 100 & 67 \\
\hline \multicolumn{9}{|c|}{ Bourbeuse River RM 24.6} \\
\hline 1978 & 390 & 18 & 49.1 & 2.06 & 2.8 & 11 & 73 & 11 \\
\hline 1997 & 310 & 12 & 8.9 & 2.10 & 4.4 & 7 & 70 & 2 \\
\hline 2005 & 240 & 2 & 1.0 & 0.56 & 0.0 & 0 & 25 & 0 \\
\hline \multicolumn{9}{|c|}{ Bourbeuse River RM 53.9} \\
\hline 1978 & 125 & 22 & 238.1 & 2.39 & 3.4 & 40 & 53 & 27 \\
\hline 1997 & 130 & 18 & 66.9 & 1.81 & 5.5 & 29 & 68 & 50 \\
\hline 2001 & 400 & 20 & 23.6 & 2.42 & 5.1 & 49 & 45 & 15 \\
\hline 2002 & 75 & 8 & 16.8 & 1.89 & 0.0 & 57 & 33 & 5 \\
\hline 2005 & 300 & 20 & 41.8 & 2.03 & 9.6 & 29 & 67 & 40 \\
\hline \multicolumn{9}{|c|}{ Bourbeuse River RM 66.3} \\
\hline 1978 & 510 & 21 & 46.5 & 2.22 & 1.0 & 45 & 50 & 11 \\
\hline 1997 & 340 & 17 & 48.0 & 2.14 & 6.3 & 39 & 57 & 38 \\
\hline 2008 & 120 & 8 & 35.0 & 1.78 & 0.0 & 46 & 54 & 34 \\
\hline \multicolumn{9}{|c|}{ Big River RM 10.3} \\
\hline 1978 & 600 & 13 & 70.0 & 0.54 & 0.3 & 94 & 5 & 91 \\
\hline 1997 & 300 & 15 & 52.6 & 1.69 & 0.8 & 71 & 27 & 66 \\
\hline 2002 & 102 & 8 & 27.1 & 1.40 & 0.0 & 63 & 37 & 76 \\
\hline 2007 & 110 & 11 & 40.4 & 1.66 & 1.4 & 66 & 34 & 66 \\
\hline 2008 & 300 & 16 & 36.4 & 1.67 & 1.7 & 73 & 26 & 66 \\
\hline \multicolumn{9}{|c|}{ Big River RM 62.7} \\
\hline 1978 & 150 & 6 & 8.4 & 1.43 & 57.1 & 10 & 29 & 0.0 \\
\hline 1997 & 240 & 0 & 0.0 & 0.00 & 0.0 & 0 & 0 & 0.0 \\
\hline 2008 & 250 & 1 & 0.2 & 0.00 & 0.0 & 0 & 100 & 100 \\
\hline \multicolumn{9}{|c|}{ Big River RM 65.7} \\
\hline 1978 & 105 & 1 & 1.1 & 0.00 & 0 & 0 & 100 & 0 \\
\hline 1997 & 160 & 4 & 7.5 & 1.19 & 45 & 20 & 80 & 0 \\
\hline 2008 & 150 & 2 & 0.8 & 0.69 & 50 & 50 & 50 & 0 \\
\hline
\end{tabular}



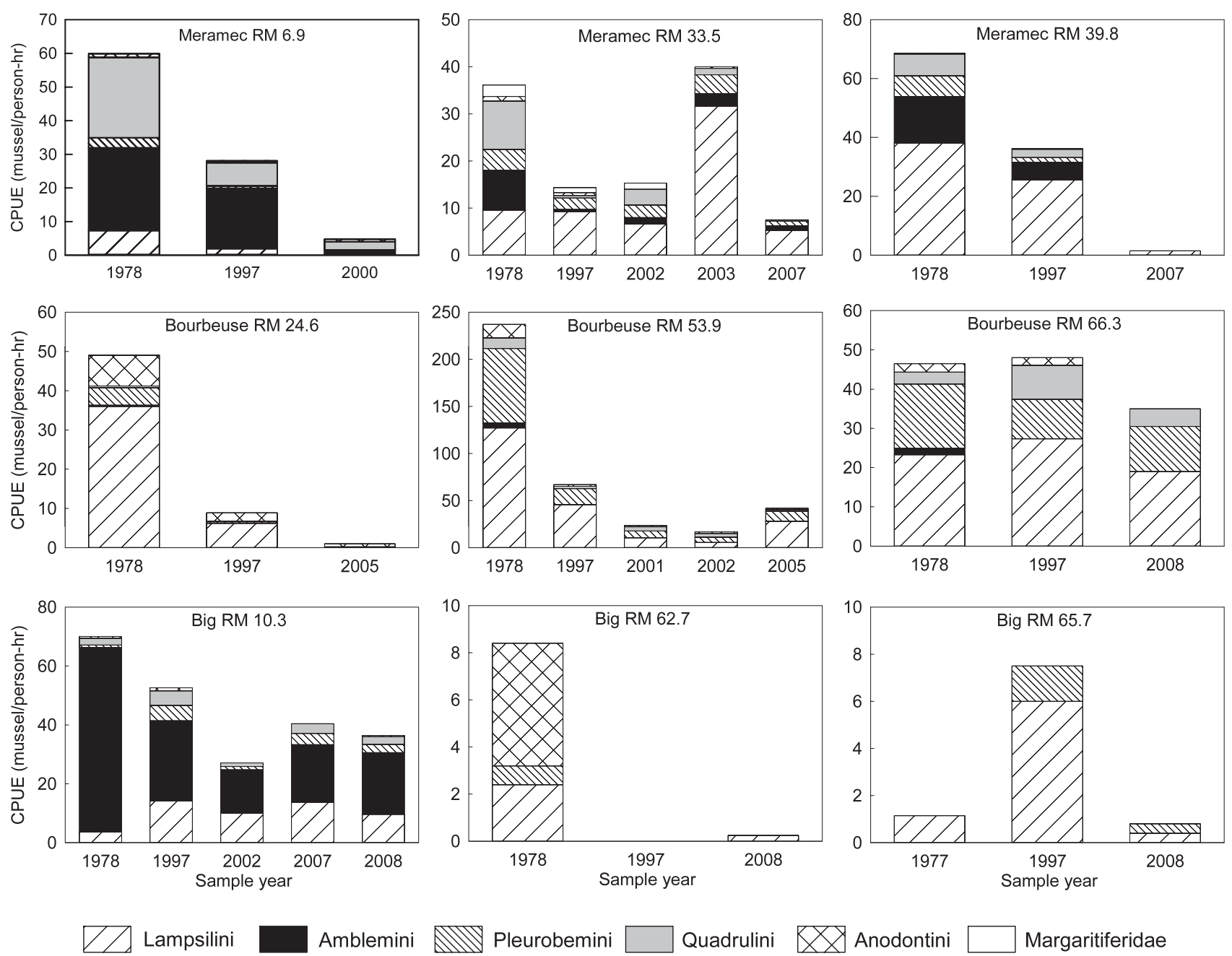

Amblemini

Pleurobemini

Quadrulini

Anodontini

Margaritiferidae

Figure 4. Change in catch per unit effort (CPUE) by mussel taxa at 1978 sites in the Meramec River basin, Missouri, resampled after 1997. RM, river mile.

the upper Meramec River and the upper Big River. The differences in mussel diversity and abundance among rivers could be attributed to several factors, including differences in geology, water flow, water depth, substrate, sedimentation, fish host assemblages, and water quality. Loss of mussels in the upper Meramec River may be related to gravel routing, the process where accumulations of excess bed load move downstream and cause channel instability (Jacobson and Gran 1999), or to lack of fish hosts. The low abundance and diversity of mussels in the Big River coincide with mining impacts in the upper basin (Roberts et al. 2009). Besser et al. (2009a, $2009 \mathrm{~b})$ reported that the metal-contaminated sediments collected from the Big River were toxic to mussels in laboratory tests. Further declines of mussel assemblages in the lower Big River may be expected if mine wastes continue to move downstream (Roberts et al. 2009). Mine wastes moving out of the Big River and into the Meramec River also are a concern for resource managers because of the diverse mussel assemblages in the Meramec River downstream from its confluence with the Big River.
Given our current understanding of mussel diversity and abundance in the Meramec River basin, several locations could be considered for further evaluation to understand the reason they have maintained the relatively robust mussel communities historically present. Mussel assemblages found in the Meramec River between RM 28.4 and RM 59.5 were generally more diverse and abundant compared with other areas, both upstream and farther downstream, based on 1997 collections. This reach is one of the few in the basin where species colonization has exceeded extirpation. The exact reasons that mussel diversity and abundance have remained robust in this reach is uncertain, but it has a considerable amount of anthropogenic impact, both instream and in the adjacent watershed, from mining, commercial and residential development, stormwater inputs, and increased bed-load movement. The reach is associated, at least in part, with increased gradients, few long pools, and bluff faces that provide stability. Multiple factors may be influencing mussel assemblages given differences in Pe and Pc in other reaches of the Meramec River. 
Several factors are suspected to have contributed to mussel declines in the Meramec River basin. The loss of riparian vegetation is the primary source of excess sedimentation in the basin, resulting in increased overland erosion, water temperatures, stream bed erosion and degradation, channel degradation, and altered stream geomorphology (Roberts and Bruenderman 2000). Therefore, restoring and protecting existing riparian habitats, especially in the headwaters, may help to protect mussel populations in the Meramec River basin. Restoration efforts are currently underway in the basin to reforest 50-100-foot buffer areas and limit livestock watering areas along streams to improve aquatic habitat (K. Flores, Missouri Department of Conservation, personal communication). The Meramec River basin has 31 active permits for in-stream sand and gravel mining, with most concentrated in the Meramec River; other in-stream sand and gravel mining is conducted by individuals for personal use or political subdivisions (e.g., county highway departments), which does not require permits. It is unknown what effect gravel mines have had on mussel assemblages in the Meramec River basin, but they have been directly implicated in the local extirpation of mussel communities from reaches of the Osage River in central Missouri (Grace and Buchanan 1981). Grace and Buchanan (1981) also reported that turbidity significantly increased and channel depth was altered downstream of sand and gravel dredging operations. Limiting the effects of instream sand and gravel mining could help reduce substrate instability, bank erosion, sedimentation, pollutant release (Brown et al. 1998; Hubbs et al. 2006), and the risk of physical habitat changes to existing mussel beds.

Protecting water quality in the Meramec River basin is also an important consideration for mussel conservation. Studies to determine water-quality needs for mussels have been conducted and interpreted relative to conservation of populations in the Meramec River (Hinck et al. 2011). However, parameters including temperature, $\mathrm{pH}$, alkalinity, hardness, dissolved oxygen, turbidity, conductivity, ammonia, nitrates, and sulfates have been measured only occasionally at mussel assemblages in the basin (Roberts and Bruenderman 2000). More studies are needed to determine the extent to which water quality is a limiting factor (Hinck et al. 2011). The mining of heavy metals has negatively impacted biota in the Big River, where zinc, lead, and cadmium deposited in streambed sediments have accumulated in biota downstream of the mining district (Besser et al. 2009b; Roberts et al. 2009; Allert et al. 2010). The failure of tailing pond dams, continual erosion of tailing piles, and exposure to contaminated sediments have eliminated much of the benthic community, including mussel populations, in the Big River (Schmitt et al. 1987; Besser et al. 2009a, 2009b; Roberts et al. 2009). Quantitative chemicalcontaminant data specific to mussels in the Big River are limited to lead and cadmium concentrations in $L$. cardium (Czarnezki 1987; Schmitt et al. 1987). In addition to lead mining, contaminants from other point (e.g., wastewater treatment plant) and nonpoint pollution (e.g., urban and agricultural runoff) can also impact water quality in the Meramec River basin. Based on the toxicological literature, mussels are particularly sensitive to ammonia, copper, zinc, lead, certain pesticides, pharmaceuticals, and personal care products (Augspurger et al. 2007; Wang et al. 2010, 2011a, 2011b); monitoring these compounds in water could be a conservation priority in the basin.

Invasive species may also affect mussels in the basin; $C$. fluminea is found in the Meramec, Bourbeuse, and Big rivers and Dreissena polymorpha has been found in the lower Meramec River. Researchers have hypothesized that invasive species may compete with native mussel species for food and habitat (Neves 1987; Ricciardi 2003), introduce diseases and parasites (Neves 1987; Ricciardi 2003), and directly affect native mussels because of increased ammonia production (Cherry et al. 2005; Cooper et al. 2005). Programs to monitor invasive species in the Meramec River basin have not been established. Monitoring and controlling invasive species could be considered when developing strategies to protect mussel diversity and density in the basin.

Overall, the loss of species and assemblages from 1978 to 1997 is cause for concern to federal and state agencies responsible for mussel conservation in the Meramec River basin because local extirpation is not speciesspecific and is occurring at a relatively high rate. The loss appears to be driven by physical habitat changes, including bank erosion, unstable substrates, and sedimentation, as well as chemical contamination from mining. Further loss of mussel diversity and abundance may be exacerbated if fish host assemblages change, invasive species become established, or water quality degrades. Ultimately, ecological problems in the headwaters of the basin need to be identified and remedied for the long-term conservation of mussels throughout the Meramec River basin.

\section{Supplemental Material}

Please note: The Journal of Fish and Wildlife Management is not responsible for the content or functionality of any supplemental material. Queries should be directed to the corresponding author for the article.

Figure S1. Comparison of mussels collected in 1978 (gray) and 1997 (black) in the Meramec River basin, Missouri. Parameters include species richness, catch per unit effort (CPUE), Shannon diversity index (SDI), relative abundance of Missouri state species of conservation concern (SOCC), relative abundance of common species (A. plicata, A. ligamentina), and relative abundance of Lampsilini and species in the tribes Amblemini, Pleurobemini, and Quadrulini (APQ taxa).

Table S1. Extirpation proportion (Pe) and colonization proportion (Pc) of unionid mussels in the Meramec River basin, Missouri, found in the Meramec River downstream of RM $28.4(n=4)$, Meramec River between RM 28.4 and $59.5(n=8)$, and Meramec River upstream of RM 59.5 ( $n=16)$, Bourbeuse River $(n=17)$, and Big River $(n=5)$ based on qualitative survey data from 1978 (Buchanan 1980) and 1997 (Roberts and Bruenderman 
2000). Bold values indicate that Pc was greater than Pe for the species.

Table S2. Historical distribution of Missouri species of conservation concern (SOCC) by river mile (RM) in the Meramec River basin. Plain text, species present in 1978 only; bold text, species present after 1978; underlined text, species not present in 1978. Footnotes indicate the most recent observation at sites resampled after 1997 (Meramec RM 6.9, 33.5, and 39.8; Bourbeuse RM 24.6, 53.9, and 66.3; Big RM 10.3, 62.7, and 65.7); bolded site numbers with no associated footnote indicate that the species was last observed in 1997. The mean species richness at a site with each SOCC is also presented (range in parenthesis).

Table S3. Unionid mussels found in the Meramec River ( $n=28)$, Bourbeuse River $(n=17)$, and Big River ( $n$ $=5$ ) of the Meramec River basin, Missouri, based on qualitative survey data from 1978 (Buchanan 1980) and 1997 (Roberts and Bruenderman 2000). Data presented include the number of sites where the individuals were found, the number of individuals collected, and the catch per unit effort (CPUE; mussels/person-hour).

Supplemental Figure and Tables found at DOI: http:// dx.doi.org/10.3996/052012-JFWM-038.S1 (114 KB DOCX).

Data S1. Field data from 1977 to 1978 and 1997 surveys conducted in the Meramec, Big, and Bourbeuse rivers, Missouri; sites were sampled for freshwater mussels.

Found at DOI: http://dx.doi.org/10.3996/052012-JFWM038.S2 (3415 KB XLSX).

Reference S1. Barnhart MC. 2009. Propagation of endangered native mussels for research and recovery. Final Report completed for Missouri Department of Conservation and U.S. Fish and Wildlife Service, Columbia, Missouri.

Found at DOI: http://dx.doi.org/10.3996/052012-JFWM038.S3 (389 KB PDF).

Reference S2. Besser JM, Brumbaugh WG, Hardesty DK, Hughes JP, Ingersoll CG. 2009b. Assessment of metalcontaminated sediments from the Southeast Missouri (SEMO) mining district using sediment toxicity tests with amphipods and freshwater mussels. Report submitted to U.S. Fish and Wildlife Service, Columbia, Missouri.

Found at DOI: http://dx.doi.org/10.3996/052012-JFWM038.S4 (1095 KB PDF).

Reference S3. Grace TB, Buchanan AC. 1981. Naiades (mussels) of the lower Osage River, Tavern Creek, and Maries River, Missouri. Jefferson City, Missouri: Missouri Department of Conservation.

Found at DOI: http://dx.doi.org/10.3996/052012-JFWM038.S5 (7005 KB PDF).

Reference S4. Hinck JE, Ingersoll CG, Wang N, Augspurger T, Barnhart MC, McMurray SE, Roberts AD, Schrader L. 2011. Threats of habitat and water-quality degradation to mussel diversity in the Meramec River basin, Missouri, USA. U.S. Geological Survey Open-File Report 2011-1125.

Found at DOI: http://dx.doi.org/10.3996/052012-JFWM038.S6; also available at http://pubs.usgs.gov/of/2011/1125 (504 KB PDF).
Reference S5. Missouri Department of Conservation. 2008. Missouri mussel conservation and management plan. Columbia, Missouri: Missouri Department of Conservation Resource Science Division.

Found at DOI: http://dx.doi.org/10.3996/052012-JFWM038.S7 (1291 KB PDF).

Reference S6. Neves RJ. 1987. Recent die-offs of freshwater mussels in the United States: an overview. Pages 7-18 in Neves RJ, editor. Proceedings of the workshop on die-offs of freshwater mussels in the United States. Blacksburg, Virginia: Virginia Tech Press.

Found at DOI: http://dx.doi.org/10.3996/052012-JFWM038.S8 (130 KB PDF).

Reference S7. Roberts AD, Bruenderman S. 2000. A reassessment of the status of freshwater mussels in the Meramec River basin, Missouri. Jefferson City, Missouri: Missouri Department of Conservation.

Found at DOI: http://dx.doi.org/10.3996/052012-JFWM038.S9 (9674 KB PDF).

Reference S8. Roberts AD, Mosby D, Weber J, Besser J, Hundley J, McMurray SE, Faiman JS. 2009. An assessment of freshwater mussel (Bivalvia: Margaritiferidae and Unionidae) populations and heavy metal sediment contamination in the Big River, Missouri. U.S. Fish and Wildlife Service, U.S. Geological Survey, and Missouri Department of Conservation, Columbia, Missouri.

Found at DOI: http://dx.doi.org/10.3996/052012-JFWM038.S10 (3057 KB PDF).

Reference S9. Schmitt CJ, Finger SE, May TW, Kaiser MS. 1987. Bioavailability of lead and cadmium from mine tailings to the pocketbook mussel (Lampsilis ventricosa). Pages 115-142 in Neves RJ, editor. Rock Island, Illinois: Proceedings of the Workshop on Die-offs of Freshwater Mussels in the United States.

Found at DOI: http://dx.doi.org/10.3996/052012-JFWM038.S11 (3 MB PDF).

\section{Acknowledgments}

Funding for this project was provided by Area Strategic Integrated Science and Technology Funds of the U.S. Geological Survey.

J. Scott Faiman, Jen Girondo, and Kevin Meneau provided additional information on native mussels in the Meramec River basin, and Aaron Garringer produced the map. Lynn Schrader helped with initial project coordination. Barry Poulton, Christopher Schmitt, two anonymous reviewers, and the journal Subject Editor reviewed earlier drafts of this paper.

Any use of trade, product, or firm names is for descriptive purposes only and does not imply endorsement by the U.S. Government.

\section{References}

Abell RA, Olson DM, Dinerstein E, Hurley PT, Diggs JT, Eichbaum W, Walters S, Wettengel W, Allnutt T, Louks CJ, Hedao P. 2000. Freshwater ecoregions of North America: a conservation assessment. Washington, D.C.: Island Press. 
Allert AL, DiStefano RJ, Fairchild JF, Schmitt CJ, Brumbaugh WG. 2010. Effects of mining-derived metals on crayfish in the Big River of southeast Missouri. Missouri Department of Conservation Science Notes 5:1.

Annis GM, Diamond DD, Garringer AJ. 2009. Streamreach specific watershed data: threats to aquatic ecosystem integrity. Jefferson City, Missouri: Final Report and Data for Missouri Department of Natural Resources. Available: http://morap.missouri. edu/Publications.aspx?Publicationld =60 (July 2012).

Augspurger T, Dwyer FJ, Ingersoll CG, Kane CM. 2007. Editorial: advances and opportunities in assessing the contaminant sensitivity of freshwater mussel early life stages. Environmental Toxicology and Chemistry 26: 2025-2028.

Barnhart MC. 2009. Propagation of endangered native mussels for research and recovery. Final Report. Columbia, Missouri: Missouri Department of Conservation and U.S. Fish and Wildlife Service. (see Supplemental Material, Reference S1, http://dx.doi. org/10.3996/052012-JFWM-038.S3).

Besser JM, Brumbaugh WG, Allert AL, Schmitt CJ, Ingersoll CG. 2009a. Ecological impacts of lead mining on streams of the Missouri Ozarks: toxicity of whole sediment and pore water. Ecotoxicology and Environmental Safety 72:516-526.

Besser JM, Brumbaugh WG, Hardesty DK, Hughes JP, Ingersoll CG. 2009b. Assessment of metal-contaminated sediments from the Southeast Missouri (SEMO) mining district using sediment toxicity tests with amphipods and freshwater mussels. Columbia, Missouri: Report submitted to U.S. Fish and Wildlife Service (see Supplemental Material, Reference S2, http://dx.doi.org/ 10.3996/052012-JFWM-038.S4).

Besser JM, Brumbaugh WG, May TM, Schmitt CJ. 2007. Biomonitoring of lead, zinc, and cadmium in streams draining lead-mining and non-mining areas, southeast Missouri. Environmental Monitoring and Assessment 129:227-241.

Brown AV, Lyttle KB, Brown KB. 1998. Impacts of gravel mining on gravel bed streams. Transactions of the American Fisheries Society 127:979-994.

Buchanan AC. 1980. Mussels (Naiades) of the Meramec River basin, Missouri. Missouri Department of Conservation Aquatic Series 17.

Carter JG, Altaba CR, Anderson LC, Araujo R, Biakov AS, Bogan AE, Campbell DC, Campbell M, Jin-hua C, Cope JCW, Delvene G, Dijkstra HH, Zong-jie F, Gardner RN, Gavrilova VA, Goncharova IA, Harries PJ, Hartman JH, Hautmann M, Hoeh WR, Hylleberg J, Bao-yu J, Johnston P, Kirkendale L, Kleemann K, Koppka J, Kř́iž J, Machado D, Malchus N, Márquez-Aliaga A, Masse JP, McRoberts CA, Middelfart PU, Mitchell S, Nevesskaja LA, Özer S, Pojeta J Jr, Polubotko IV, Pons JM, Popov S, Sánchez T, Sartori AF, Scott RW, Sey II, Signorelli JH, Silantiev VV, Skelton PW, Steuber T, Waterhouse JB, Wingard GL, Yancey T. 2011. A synoptical classification of the Bivalvia (Mollusca). University of Kansas,
Paleontological Institute, Paleontological Contributions 4:1-47.

Cherry DS, Scheller JL, Cooper NL, Bidwell JR. 2005. Potential effects of Asian clam (Corbicula fluminea) die-offs on native freshwater mussels (Unionidae) I: water-column ammonia levels and ammonia toxicity. Journal of the North American Benthological Society 24:369-380.

Cooper NL, Bidwell JR, Cherry DS. 2005. Potential effects of Asian clam (Corbicula fluminea) die-offs on native freshwater mussels (Unionidae) II: porewater ammonia. Journal of the North American Benthological Society 24:381-394.

Czarnezki JM. 1985. Accumulation of lead in fish from Missouri streams impacted by lead mining. Bulletin of Environmental Contamination and Toxicology 34:736745.

Czarnezki JM. 1987. Use of the pocket mussel, Lampsilis ventricosa, for monitoring heavy metal pollution in an Ozark stream. Bulletin of Environmental Contamination and Toxicology 38:641-646.

[ESA] U.S. Endangered Species Act of 1973, as amended, Pub. L. No. 93-205, 87 Stat. 884, 16 USC 1531 et seq., (Dec. 28, 1973). Available: http://www.fws.gov/endangered/ esa-library/pdf/ESAall.pdf.

Gale NL, Adams CD, Wixson BG, Loftin KA, Huang Y. 2002. Lead concentrations in fish and river sediments in the old lead belt of Missouri. Environmental Science and Technology 36:4262-4268.

Gotelli NJ. 2001. A Primer of Ecology. Sunderland, MA: Sinauer.

Grace TB, Buchanan AC. 1981. Naiades (mussels) of the lower Osage River, Tavern Creek, and Maries River, Missouri. Jefferson City, Missouri: Missouri Department of Conservation (see Supplemental Material, Reference S3, http://dx.doi.org/10.3996/052012-JFWM-038.S5).

Haag WR. 2009. Past and future patterns of freshwater mussel extinctions in North America during the Holocene. Pages 107-128 in Turvey ST, editor. Holocene extinctions. Oxford, UK: Oxford University Press.

Haag WR, Rypel AL. 2011. Growth and longevity in freshwater mussels: evolutionary and conservation implications. Biological Reviews 86:225-247.

Haag WR, Warren ML Jr. 2010. Diversity, abundance, and size structure of bivalve assemblages in the Sipsey River, Alabama. Aquatic Conservation: Marine and Freshwater Ecosystems 20:655-667.

Hanlon SD, Petty MA, Neves RJ. 2009. Status of native freshwater mussels in Copper Creek, Virginia. Southeastern Naturalist 8:1-18.

Hinck JE, Ingersoll CG, Wang N, Augspurger T, Barnhart MC, McMurray SE, Roberts AD, Schrader L. 2011. Threats of habitat and water-quality degradation to mussel diversity in the Meramec River basin, Missouri, USA. U.S. Geological Survey Open-File Report 20111125 (see Supplemental Material, Reference S4, http:// dx.doi.org/10.3996/052012-JFWM-038.S6); also available: http://pubs.usgs.gov/of/2011/1125. 
Homer C, Huang C, Yang L, Wylie B, Coan M. 2004. Development of a 2001 National Landcover Database for the United States. Photogrammetric Engineering and Remote Sensing 70:829-840.

Huan J, Cao Y, Cummings KS. 2011. Assessing sampling adequacy of mussel diversity in wadeable Illinois streams. Journal of the North American Benthological Society 20:923-934.

Hubbs D, McKinney D, Sims D, Lanier S, Black P. 2006. Aggregate extraction impacts on Unionid mussel species richness and density. Proceedings of the Annual Conference of Southeastern Association of Fish and Wildlife Agencies 60:169-173.

Jacobson RB, Gran KB. 1999. Gravel routing from widespread, low-intensity landscape disturbance, Current River basin, Missouri. Earth Surf Processes and Landforms 24:897-917.

Lydeard C, Cowie R, Ponder W, Bogan A, Bouchet P, Clark S, Cummings KS, Frest TJ, Gargominy O, Herbert DG, Hershler R, Perez KE, Roth B, Seddon MB, Strong EE, Thompson FB. 2004. The global decline of nonmarine mollusks. BioScience 54:321-330.

Missouri Department of Conservation. 2008. Missouri mussel conservation and management plan. Columbia, Missouri: Missouri Department of Conservation, Resource Science Division (see Supplemental Material, Reference S5, http://dx.doi.org/10.3996/052012-JFWM038.S7).

Neves RJ. 1987. Recent die-offs of freshwater mussels in the United States: an overview. Pages 7-18 in Neves $\mathrm{RJ}$, editor. Proceedings of the workshop on die-offs of freshwater mussels in the United States. Blacksburg, Virginia: Virginia Tech Press (see Supplemental Material, Reference S6, http://dx.doi.org/10.3996/052012JFWM-038.S8).

Niethammer KR, Atkinson RD, Baskett TS, Samson FB. 1985. Metals in riparian wildlife of the lead mining district of southeastern Missouri. Archives of Environmental Contamination and Toxicology 14:213-223.

Perles SJ, Christian AD, Berg DJ. 2003. Vertical migration, orientation, aggregation, and fecundity of the freshwater mussel Lampsilis siliquoidea. Ohio Journal of Science 103(4):73-78.

Ricciardi A. 2003. Predicting the impacts of an introduced species from its invasion history: an empirical approach applied to zebra mussel invasions. Freshwater Biology 48:972-981.

Roberts AD, Bruenderman S. 2000. A reassessment of the status of freshwater mussels in the Meramec River basin, Missouri. Jefferson City, Missouri: Missouri Department of Conservation (see Supplemental Material, Reference S7, 10.3996/052012-JFWM-038.S9).

Roberts AD, Mosby D, Weber J, Besser J, Hundley J, McMurray SE, Faiman JS. 2009. An assessment of freshwater mussel (Bivalvia: Margaritiferidae and Unionidae) populations and heavy metal sediment contamination in the Big River, Missouri. U.S. Fish and Wildlife Service, U.S. Geological Survey, and Missouri
Department of Conservation, Columbia, Missouri. (see Supplemental Material, Reference S8, 10.3996/052012JFWM-038.S10).

Schmitt CJ, Finger SE, May TW, Kaiser MS. 1987. Bioavailability of lead and cadmium from mine tailings to the pocketbook mussel (Lampsilis ventricosa). Pages 115-142 in Neves RJ, editor. Rock Island, Illinois: Proceedings of the Workshop on Die-offs of Freshwater Mussels in the United States (see Supplemental Material, Reference S9, http://dx.doi.org/10.3996/ 052012-JFWM-038.S11).

Shannon CE. 1948. A mathematical theory of communication. Bell System Technical Journal 27:379-423, 623-656.

Strayer DL, Smith DR. 2003. A guide to sampling freshwater mussel populations. American Fisheries Society Monographs 8:1-103.

Tetzloff J. 2001. Survival rates of Unionid species following a low oxygen event. Ellipsaria 3:18-19.

U.S. Fish and Wildlife Service. 2011. Summary of listed species, listed populations and recovery plans. Available: http://ecos.fws.gov/tess_public/pub/Boxscore.do (June 2011).

Vaughn CC. 2012. Life history traits and abundance can predict local colonization and extinction rates of freshwater mussels. Freshwater Biology 57:982-992.

Vaughn CC, Taylor CN, Eberhard KJ. 1997. A comparison of the effectiveness of timed searches vs. quadrat sampling in mussel surveys. Pages 157-162 in Cummings DS, Buchanan AC, Koch LM, editors. Conservation and management of freshwater mussels II. Rock Island, Illinois: Proceedings of an Upper Mississippi River Conservation Committee symposium.

Wang N, Consbrock RA, Ingersoll CG, Barnhart MC. 2011 a. Sensitivity of juvenile freshwater mussels (fatmucket, Lampsilis siliquoidea) to ammonia in chronic water exposure with or without the presence of sediment. Environmental Toxicology and Chemistry 30:22702276.

Wang N, Ingersoll CG, Ivey CD, Hardesty DK, May TW, Augspurger T, Roberts AD, van Genderen E, Barnhart MC. 2010. Sensitivity of early life stages of freshwater mussels (Unionidae) to acute and chronic toxicity of lead, cadmium, and zinc in water. Environmental Toxicology and Chemistry 29:2053-2063.

Wang N, Mebane CA, Kunz JL, Ingersoll CG, Brumbaugh WG, Santore RC, Gorsuch JW, Arnold WR. 2011b. Influence of dissolved organic carbon on the toxicity of copper to a unionid mussel (Villosa iris) and a cladoceran (Ceriodaphnia dubia) in acute and chronic water exposures. Environmental Toxicology and Chemistry 30:2115-2125.

Warren ML Jr, Haag WR. 2005. Spatio-temporal patterns of the decline of freshwater musses in the Little South Fork Cumberland River, USA. Biodiversity and Conservation 14:1383-1400.

Wendeln KL, Runkle JR, Watters GT. 2009. The freshwater mussels (Unionidae) of Twin Creek, Southwest Ohio. Journal of Freshwater Ecology 24:351-460. 